\title{
Communities Left Behind: Can Nonviable Places Become Smart?
}

\section{David L. Barkley*}

\begin{abstract}
Endogenous community development receives much attention as an economic development strategy for rural areas. The literature suggests that endogenous development is more likely to occur in "smart communities" communities characterized by empowered individuals, skilled leadership, innovative institutions, social capital, and sense of place. This paper provides an overview of the characteristics of "smart communities" and suggests issues for further research. Research topics suggested include defining and measuring qualitative factors associated with endogenous development, determining which qualitative factors are changeable over time, understanding the roles of history and path dependency in community development, and determining if communities "made smart" have better economic development experiences.
\end{abstract}

One of my fields of study in graduate school was United States economic history. I am no longer a practicing economic historian; however, I maintain an interest in the subject, especially the economic history of rural America. Part of my continuing education on this topic involves visiting the historical landmarks, battlefields, museums, and antique shops of rural communities. On vacations and business trips, I avoid interstate highways in hopes of happening upon historical jewels such as the No Law West of the Pecos Museum or the site of the nation's first daylight bank robbery.

These past twenty-five years of traveling on America's back roads have led to two observations regarding the state of rural America. First, small towns have become more similar in appearances. The crossroads markets have been replaced by sterile convenience stores and main street cafes have been supplanted by fast food franchises. The architecture of residential and commercial buildings also has become similar over time, much the result of the proliferation of mobile homes and strip malls anchored by WalMart-like stores. This homogenization of small towns has made rural America a less interesting place to visit and a more difficult place to find a good chicken fried steak dinner.

My second observation is that small towns have become less similar in terms of their economic vitality and quality of life. Many rural communities appear to be prosperous and desirable locations to operate businesses and raise families. Such communities in the rural South are pleasant surprises to nonSoutherners whose perceptions of small-town southern life were formed by movies such as "Coal Miner's Daughter," "Norma Rae," and "In the Heat of the Night."

*Professor, Department of Agricultural and Applied Economics, Clemson University. Presented as the Presidential Address at the annual meeting of the Southern Regional Science Association, Savannah, Georgia, April 1998. 
Numerous other small towns, on the other hand, greet visitors with abandoned main street buildings, deteriorating public infrastructure, and low quality of housing. As a regional scientist, I wonder what activities support these declining communities and what forces contributed to their present state. As an individual and parent, I also can't help but wonder why people remain in locations that appear to offer so little.

These "communities left behind" provide, in my opinion, one of the more interesting topics for regional science research. Regional scientists have contributed much to our understanding of the factors associated with the economic decline of these places. Our theories and empirical studies provide significant insights into the debilitating effects of the restructuring of economic activity; deregulation of the financial, communication, and transportation industries; introduction of new technologies; and integration into the world economy (Henry, Drabenstott, and Gibson 1988; Kale 1989; Barkley 1995; Smith 1996). Our research also has contributed significantly to policy makers' understandings of the efficacy of alternative economic development initiatives. A wealth of literature exists on the potentials for, and pitfalls of, economic development strategies such as industrial recruitment, entrepreneurship and small business development, alternative agriculture, business retention and expansion, and infrastructure and human capital development (Barkley 1993; Blakely 1994; Galston and Baehler 1995).

Regional scientists have been, however, less successful in understanding why specific economic development strategies and programs work well in some communities but fail in others. As a result, many regional scientists believe that a change in research directions is needed if we are to offer significant new insights into policies for enhancing the economic well-being of declining rural areas. A research area that has received much attention is endogenous community development or "growth from within" (see, for example, Coffey and Polése 1984; Doeringer and Terkla 1990; Flora et al. 1992; Green et al. 1993; McDowell 1995). Proponents of "growth from within" argue that community economic vitality depends on the community's ability to adapt to, and take advantage of, changing conditions. This adaptive efficiency, in turn, is attributable to characteristics of the local political, economic, and social environments. Thus local economic development prospects may be enhanced by encouraging and enabling changes in the characteristics of these local environments.

Is "growth from within" a promising strategy for communities left behind? Before I address this question, I believe it would be useful to identify and describe some of these rural places left behind. I could provide names and details for rural South Carolina communities left behind, some within a short drive of here. But since the South Carolina legislature is discussing the elimination of tenure at its state universities, I will refrain from being that specific. Instead, as examples of rural places left behind, I have selected the 181 nonmetro counties in the South with 1995 per capita incomes less than 60 percent of the national average. Obviously per capita income is an imperfect measure of economic well-being, and 
this sample does not capture all rural areas with depressed economic conditions (Hansen 1995). Yet I believe we can agree that these counties are representative of rural areas that would benefit from additional economic development research and extension programs.

These 181 low-income rural counties share a number of characteristics. First, they are generally small and remote. Only 70 of the counties are adjacent to metropolitan areas and only 50 had populations greater than 15,000 in 1990. Low population densities and small-scale markets limit the competitiveness and growth potential of area businesses. And remoteness from urban areas diminishes the benefits from spillovers of metropolitan growth (Henry, Barkley, and Bao 1997).

Second, as expected given the selection criterion, these counties have exceptionally high unemployment rates, incidences of poverty, and reliances on transfer payments as a share of total personal income (Appendix Table A). These measures of economic well-being generally do not reflect economies suffering from temporary setbacks. Many of the counties also were classified by the USDA as persistent poverty counties based on high poverty rates for every census year starting in 1960 (Cook and Mizer 1989).

However, it is the diversity of these communities left behind that complicates research programs focused on understanding and assisting these places. The low-income counties are dispersed in clusters throughout the South (Figure 1), with geographic concentrations in Appalachia, the Mississippi Delta, the old Cotton Belt, Texas border towns, and the Texas-Oklahoma plains. The racial composition of the resident populations of these geographic clusters are dissimilar. The Appalachian counties are predominately white, the Mississippi Delta and old Cotton Belt counties generally are more than 50 percent black, the Texas border towns have large Hispanic populations, and Native Americans are represented in the Oklahoma counties.

The economic specializations of these counties are also quite diverse. The USDA (Cook and Mizer 1989) classifies 37 of these counties as farmingdependent, 32 as manufacturing-dependent, 45 as government-dependent, 18 as mining-dependent, and 11 as service-dependent. Only 38 of the counties are classified as having multiple areas of specialization.

In sum, the communities left behind are an eclectic group with different economic histories, industrial bases, institutions, and social structures. It is well recognized among regional scientists that economic development efforts must take into consideration the distinct characteristics of these subsets of communities. Yet the current political environment is such that support is unlikely for the breadth of programs needed to address the diversity of these rural areas. At the same time, welfare reform legislation and the devolution of government programs have placed greater burdens and responsibilities on local institutions. The employment generation capabilities of these rural areas must be enhanced significantly if the local job markets are to absorb many of the residents on welfare. And local tax bases must be expanded to support public programs required by devolution and a more demanding citizenry. 
The characteristics and conditions of the southern counties left behind may be viewed as strong supporting evidence for a "triage" assistance strategy rather than new "place-oriented" development programs. And most regional scientists would not recommend the extensive use of state or federal funds for traditional economic development programs for these counties. Yet many of the places left behind are not ready to "throw in the towel" and participate in an orderly and systematic depopulation. I learned this fact the hard way after suggesting a "triage" strategy in a public meeting in a rural county in South Carolina. Fortunately, candid comments from the audience regarding my intellect were cut short by a scheduled coffee break.

This experience in rural South Carolina taught me that some of these communities left behind are very interested in improving local economic opportunities, and they are willing to commit local resources to the effort. For places such as these, what are the prospects for economic development?

An interesting perspective on this issue is provided by the Mulkey, Malecki, and Burkhardt (1993) functional community approach to rural development policy. The functional approach, based on the central place hierarchy of urban places, divides all rural communities into three groups: nonviable, lucky, and smart. "Nonviable" communities are those that have become obsolete in the sense that the economic base is no longer of sufficient size to support the population and central place functions that evolved in more prosperous times. Examples include communities impacted by mine closings, the loss of textile jobs, and military base consolidations. These communities will be chararacterized by high levels of unemployment and poverty until they adapt to their new circumstances through extensive out-migration or they get lucky or become smart. "Lucky" communities are those where external forces or events contributed to new economic activities to replace or supplement their traditional or former base. Such fortuitous events might include the development of a retirement community, designation of a national park nearby, or construction of a new interstate highway interchange. And "smart" communities are those with the indigenous abilities and responses to adapt to, and take advantage of, changing economic conditions and grow from within.

At first glance, this rural community typology appears to offer little promise for the communities left behind. Most of the 181 southern counties would be buried deep in the nonviable category, and prospects for moving into the "lucky" or "smart" categories do not look good. Dwight Billings (1988), for example, suggests that a supportive environment for endogenous development is not likely to evolve in areas historically dependent upon mining or plantation agriculture. And Tomaskovic-Devey (1991) argues that in the South, state and local industrialization strategies focused on branch plant recruitment have done little to develop the local leadership and entrepreneurship necessary for endogenous development.

But rural counties do shift among categories over time. In 1970, 370 southern nonmetro counties had per capita incomes less than 60 percent of the U.S. average. Many of the 189 counties that moved above this arbitrary income threshold did so 

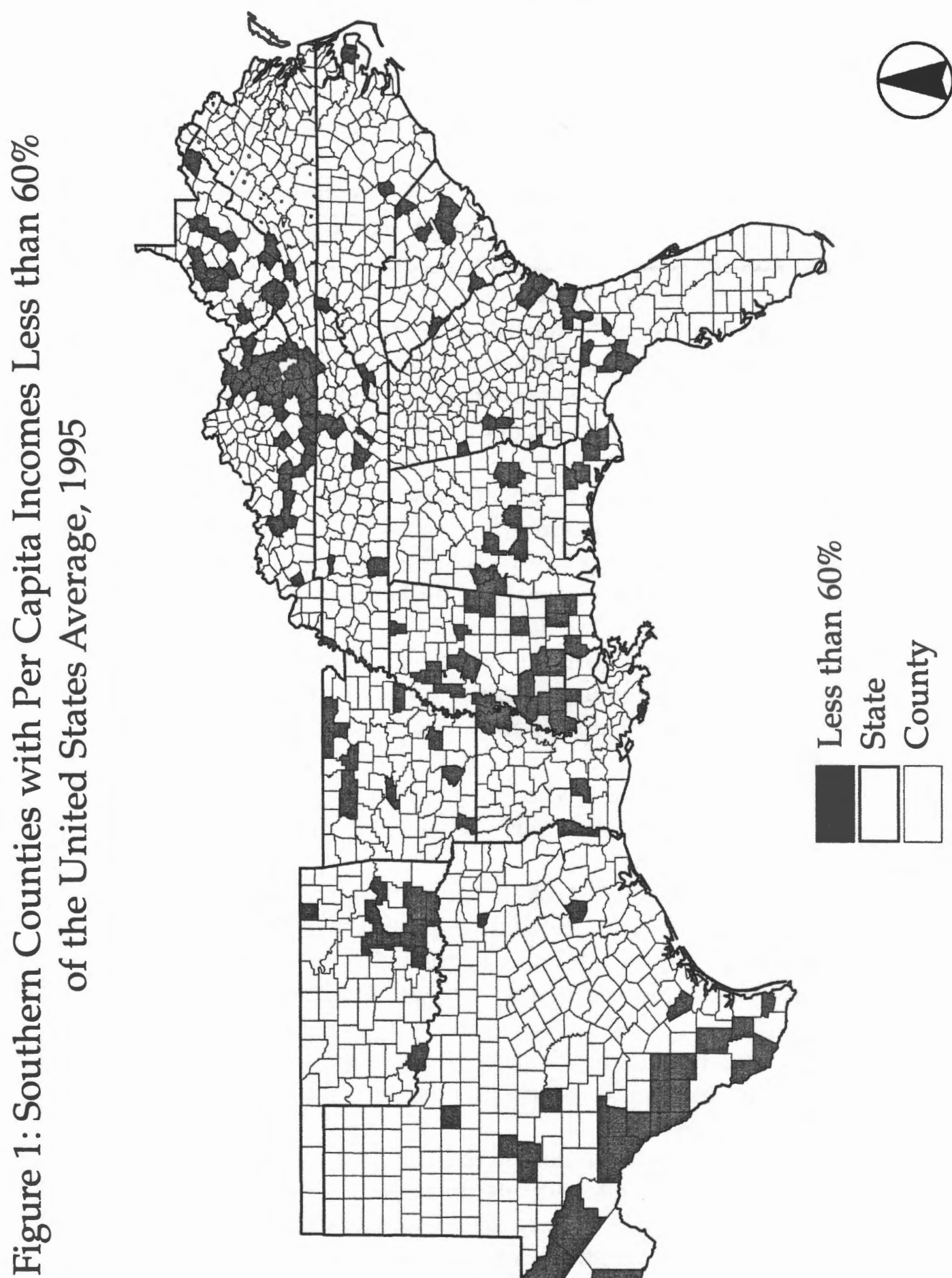
as a result of market forces and the convergence process predicted by neoclassical economic theory. Other counties were simply lucky and stumbled upon a new economic structure. But perhaps a few of these 189 southern counties "got smart" between 1970 and 1995.

Can nonviable communities "get smart" over time, or are the development opportunities of these places predestined by their economic and social history and subject to change only by some capricious event of good fortune? Recent publications on "growth from within" strategies and qualitative factors related to endogenous economic development suggest that communities may be able to influence their destiny. But this literature reminds me of a group of blind men describing an elephant. We concur that there is something before us, but we are not in complete agreement regarding what it is. For example, consider the following statements regarding the key to endogenous community development.

Individual empowerment is the foundation for collective action for community economic development. (paraphrased, Wilson 1996).

"Culture is a fundamental factor shaping the nature and achievable pace of a region's development...Cultural capital may sometimes be the key catalyst." (Batten 1993, pp. 110 and 111).

"Skilled local leaders are the bedrock of successful rural communities." (MDC Inc. 1992, p. 37).

"Institutions form the incentive structure of a society, and the political and economic institutions, in consequence, are the underlying determinants of economic performance." (North 1994, p. 359).

"...communities who bring a strong level of social capital to the process will be more likely to succeed over the long-term..." (Gaventa 1995, p. 61).

So there you have it. "Smart" communities have empowered individuals, skilled leadership, innovative institutions, cultural capital, and social capital. Other publications add local knowledge, entrepreneurial values, networks, sense of place, social entrepreneurs, and gatekeepers to this list of desirable characteristics (Malecki 1998). Or, if these attributes are highly interrelated (in other words, different parts of the same elephant), then we may refer to them as components of a more holistic concept such as a "supportive environment for endogenous development."

I believe this recent attention by regional scientists to "growth from within" provides many interesting insights into differences between nonviable and smart communities. I am not, however, ready to conclude that this area of inquiry is "pragmatic" - where pragmatic refers to the ability to develop specific local policies that make nonviable communities smart. The determination of the practical value of these interesting ideas would benefit from additional scholarly work in four interrelated areas. 
First, it would be helpful if we were able to develop a common vocabulary and proxy variables for the various qualitative factors hypothesized to be associated with a supportive environment for growth from within. In the literature, one finds references to institutional capacity, institutional embededness, institutional thickness, and institutional learning. This proliferation of jargon in the "growth from within" literature limits the usefulness of the information to researchers and practitioners.

And how can we measure concepts such as social capital, individual empowerment, or institutional capacity? Without measures for the qualitative factors, how precisely can we determine if local efforts to enhance social capital or institutional capacity are successful? Or for cross-sectional analysis, can we state that community A's environment for growth from within is preferred to that in community B rather than simply observe that A and B are different?

Assessments of the qualitative factors associated with endogenous development also must distinguish between beneficial and detrimental forms of these factors. The literature suggests that, like the "force" in the "Star Wars" trilogy, some components of the endogenous growth environment may be instruments of good as well as evil. For example, Robert Putman (1993) notes that some forms of social capital encourage social inequalities, and Ben Marsh (1987) and Roger Bolton (1992) argue that a strong sense of place can retard a community's ability to adapt to new circumstances. And in a fascinating case study of two rural Maryland communities, Meredith Ramsay (1995) documents how local social structures and institutions thwarted community economic development efforts.

Regional scientists have had only limited success in providing measures for qualitative concepts such as local quality of life or the quality of the local business environment. But interesting ideas are provided in the recent literature regarding potential measures for the qualitative concepts associated with the environment for "growth from within." Rural sociologists, for example, are investigating the potential for measuring social capital through such proxies as the number, size, and diversity of local organizations, and the extent of cooperation and networking among local and outside organizations (Hobbs 1995). And as a proxy for sense of place, Roger Bolton (1996) suggests the propensity to out-migrate in response to adverse events. Thus high out-migration rates may indicate communities with a weak sense of place.

Steve Deller suggests that significant new insights into potential measures for the subjective factors associated with endogenous community development will require that we move beyond our quantitative, market-based models and explore alternative research methods that address qualitative non-market issues. Such an approach will require greater discourse and cooperation among academic disciplines than currently exists. For instance, Roger Bolton (1996) proposes that an understanding of sense of place alone would benefit from an integration of the engineering literature on "networks," the economics literature on "adoption externalities," and the sociology literature on "social relations." This call for greater 
interdisciplinary research is made in almost every regional science association presidential address. Yet the fact that interdisciplinary research is not an original idea does not diminish its importance in understanding "growth from within."

A second research issue is to determine which of the components of our supportive environment for endogenous development are changeable in the short run or the long run and what are the determinants of change. In an excellent review of the literature, Edward Malecki (1998) finds checklists for a supportive environment and flow charts with recommended linkages and feedbacks between the players and components. These lists and flow charts contain large numbers of "actors, factors, and flows"-many more of these than are currently available in nonviable places.

So where do the nonviable communities begin given that limited resources precluded them from accomplishing all that is prescribed in the literature? Can we identify the more relevant components of the supportive environment and the more promising strategies for augmenting these components?

A suggested starting point for addressing such questions is the specification of production function relationships (Bolton 1995, 1997). For example, the "quality" of the supportive environment for growth from within may be related to the availability of local attributes such as leadership quality, density of networks, sense of place, institutional capacity, and so on. Similarly, these components of the environment may have their own production functions identifying inputs and input-output relationships. Obviously a production function's framework is too limited to capture all the synergies and reciprocities inherent in a supportive environment. However, such a perspective would encourage us to investigate complementarity and substitutability among factors, returns to factor availability, threshold effects, potential constraints, and necessary conditions for positive "input-output" relationships.

Part of this research area also will involve identifying important components of the supportive environment that are for all practical purposes unchangeable because the determinants of these components are exogenous or historically predetermined. However, identification of the difficult-to-change factors and flows will be a valuable contribution to local economic development policy. Communities deficient in these components may not be good candidates for "growth from within" if such factors are critical to success. These communities may be better served by focusing their limited economic development resources on alternative development strategies.

Third, as has been noted often in the recent literature, we need to give greater attention to the roles of history and path dependencies in our research on regional economic development (Pred 1986; Aiken 1995; Nelson 1995). Bailey and Coffey (1994) argue that the components of our supportive environment for "growth from within" are both the culmination of historical and evolutionary processes and precursors for the future. Thus attempts to change this environment must be grounded in an understanding of why the current environment evolved 
and the finite paths for change that are available given the community's history and social structure.

For most of the rural places left behind, the current leadership, institutions, and interest groups evolved to promote and perpetuate a specific way of lifeoften a way of life that favored only a few individuals (Billings 1988). A research issue before us is to determine the process by which a new social structure is established that is better able to take advantage of current and future economic opportunities. Can the appropriate new environment result from tweaking the old through current programs such as strategic planning, consensus building, leadership training, and institutional capacity building? Or, does the establishment of a conducive environment for growth from within require the creative destruction of the existing social structure before the necessary changes can be accommodated (Olson 1982)? With respect to the leadership component of the growth environment, Tomaskavic-Devey (1991, p. 112) is not optimistic that working through the existing system is a viable alternative. He states "Do not focus development strategies on existing rural economic leadership...this group is part of the problem, not the solution to rural economic development."

We also need to determine if desirable changes in the local environment for economic development occurred primarily as a result of the introduction of an outside culture. For example, Niles Hansen (1998) suggests that the conservative practices of businesses in southern France were radically transformed only after the arrival of a large IBM plant and immigrants from North Africa. Do rural communities left behind require similar external stimulants in the form of retirees moving to the area or the addition of a new branch plant operation?

Another potential exogenous force for change might be new laws and regulations. Economic historian Gavin Wright (1987) argues that the southern economic and political leadership abandoned their emphasis on regional isolation and the perpetuation of low wages only with the passing of federal minimum wage legislation. Can we identify other changes in laws and regulations that have been beneficial or detrimental to the evolution of supportive environments for local development?

Also, is a nonviable place's potential for "getting smart" enhanced or reduced if it is proximate to "smart" communities? Nearby "smart" communities may provide positive spillovers through demonstration effects and adoption externalities. Alternatively, backwash effects may exist if the "smart" community attracts resources away from nearby nonviable places. The potential for spillover and backwash effects from nearby places is a research area in which regional scientists have much to offer.

Finally, additional research is needed to determine if nonviable communities "made smart" have better economic development experiences than nonviable communities that muddle through relying on their existing economic environment. Recent studies by Tomaskovic-Devey (1991) and Leatherman and Marcouiller (1996) suggest that the benefits of a "growth from within" strategy for 
rural areas may be quite limited. We should not be surprised by these research findings. Almost ten years ago, Bill Coffey (1990, p. 75) cautioned that the "local development approach can begin to make a difference only in those circumstances where the social and economic potential for development already exists." Thus an important area of research is to identify the local and regional characteristics associated with the potential for development.

Analysis of the development consequences of promoting growth from within in nonviable rural areas probably will require an increased reliance on case studies, an approach that has been very valuable in providing insights into the workings and development of industrial districts. However, these case studies must not be limited to the "feel good" stories of communities that were successful in changing from nonviable and dying to smart and growing. Valuable insights also are provided in studies of nonviable communities that tried to become smart but failed and nonviable communities that became smart but did not develop economically. Case studies of communities where endogenous development efforts failed will provide useful information on communities' potentials for change and the efficacy of alternative "growth from within" strategies in different types of communities.

In summary, the question before us is not whether rapidly growing rural areas have different economic environments from nonviable areas. Recent research documents important differences. The relevant questions are: can conducive environments for growth from within be developed in the communities left behind and, if so, do these new environments significantly enhance the economic development prospects of these places? I do not believe these questions have been adequately researched. Yet the current rural development literature is replete with directives to focus attention and resources on institutions, leadership, social capital, etc. And community development outreach programs are providing much greater attention to the environment for endogenous development. For example, a forthcoming training program by the Heartland Center allocates one day each to the development of social capital and community leadership.

Can the "growth from within" strategy live up to all that is being promised? Or, like the growth center paradigm of the past, is "growth from within" just another intuitively attractive idea with limited practical relevance for the nonviable places?

Regional scientists have much to contribute to this topic, and I anticipate that members of the Southern Regional Science Association will take an active role in this research area because of our traditional focus on applied research and rural problems. And I am pleased to note that an excellent organized session on social relationships and economic development was held on Thursday. I look forward to more presentations on this topic in future meetings. 


\section{APPENDIX TABLE A}

Selected Characteristics for Southern Counties with Per Capita Incomes Less Than 60\% of the U.S. Average, 1995.

\begin{tabular}{|c|c|c|c|c|c|c|}
\hline & $\begin{array}{l}\text { ansfer Paymen } \\
\text { Share of } \\
\text { Personal } \\
\text { Income } 1993\end{array}$ & $\begin{array}{l}\text { ts } \\
\text { Unemployment } \\
\text { Rate } 1990\end{array}$ & $\begin{array}{c}\text { Total Resident } \\
\text { Population } 1990\end{array}$ & $\begin{array}{c}\text { Percent } \\
\text { Non-White } \\
\text { Population } 1990^{*}\end{array}$ & $\begin{array}{c}\text { Percent } \\
\text { Population } \\
\text { Below Poverty } \\
\text { Level } 1989\end{array}$ & $\begin{array}{l}\text { Per Capita } \\
\text { Income } 1995\end{array}$ \\
\hline UNITED STATES & $17.0 \%$ & $6.2 \%$ & $249,403,447$ & $19.9 \%$ & $13.1 \%$ & $\$ 23,196$ \\
\hline 01000 ALABAMA & $19.6 \%$ & $6.8 \%$ & $4,048,368$ & $26.5 \%$ & $18.3 \%$ & $\$ 19,209$ \\
\hline 01011 Bullock, AL & $32.2 \%$ & $8.1 \%$ & 11,016 & $72.4 \%$ & $36.5 \%$ & $\$ 13,144$ \\
\hline 01063 Greene, AL & $33.8 \%$ & $10.5 \%$ & 10,154 & $80.6 \%$ & $45.6 \%$ & $\$ 12,907$ \\
\hline 01085 Lowndes, AL & $30.7 \%$ & $11.7 \%$ & 12,661 & $74.8 \%$ & $38.6 \%$ & $\$ 12,472$ \\
\hline 01087 Macon, AL & $33.6 \%$ & $14.3 \%$ & 24,882 & $86.2 \%$ & $34.5 \%$ & $\$ 13,605$ \\
\hline 01105 Perry, AL & $36.8 \%$ & $7.5 \%$ & 12,706 & $64.6 \%$ & $42.6 \%$ & $\$ 12,401$ \\
\hline 01119 Sumter, AL & $30.5 \%$ & $10.6 \%$ & 16,167 & $70.6 \%$ & $39.7 \%$ & $\$ 13,073$ \\
\hline 01131 Wilcox, AL & $38.4 \%$ & $14.2 \%$ & 13,501 & $68.9 \%$ & $45.2 \%$ & $\$ 15,094$ \\
\hline 05000 ARKANSAS & $21.8 \%$ & $6.7 \%$ & $2,354,282$ & $17.4 \%$ & $19.1 \%$ & $\$ 18,097$ \\
\hline 05013 Calhoun, AR & $26.9 \%$ & $11.0 \%$ & 5,818 & $25.1 \%$ & $15.6 \%$ & $\$ 12,764$ \\
\hline 05049 Fulton, AR & $33.6 \%$ & $8.3 \%$ & 10,077 & $1.1 \%$ & $26.3 \%$ & $\$ 12,530$ \\
\hline 05073 Lafayette, AR & $30.4 \%$ & $10.6 \%$ & 9,591 & $38.7 \%$ & $34.7 \%$ & $\$ 13,348$ \\
\hline 05077 Lee, AR & $36.9 \%$ & $14.9 \%$ & 12,995 & $58.1 \%$ & $47.3 \%$ & $\$ 11,537$ \\
\hline 05079 Lincoln, AR & $25.3 \%$ & $7.9 \%$ & 13,718 & $37.2 \%$ & $26.2 \%$ & $\$ 11,405$ \\
\hline 05101 Newton, AR & $31.4 \%$ & $9.3 \%$ & 7,681 & $1.3 \%$ & $29.6 \%$ & $\$ 11,272$ \\
\hline 05105 Perry, AR & $28.4 \%$ & $7.4 \%$ & 7,963 & $2.3 \%$ & $20.3 \%$ & $\$ 13,860$ \\
\hline 05121 Randolph, AR & $28.2 \%$ & $7.6 \%$ & 16,559 & $1.4 \%$ & $20.4 \%$ & $\$ 13,889$ \\
\hline 05129 Searcy, AR & $36.8 \%$ & $9.1 \%$ & 7,811 & $0.8 \%$ & $29.9 \%$ & $\$ 13,305$ \\
\hline 05135 Sharp, AR & $36.2 \%$ & $11.4 \%$ & 14,137 & $1.6 \%$ & $21.8 \%$ & $\$ 13,637$ \\
\hline 05137 Stone, AR & $30.5 \%$ & $8.5 \%$ & 9,826 & $1.4 \%$ & $26.0 \%$ & $\$ 13,679$ \\
\hline 12000 FLORIDA & $18.4 \%$ & $5.7 \%$ & $13,019,115$ & $17.4 \%$ & $12.7 \%$ & $\$ 23,031$ \\
\hline 12013 Calhoun, FL & $33.2 \%$ & $6.3 \%$ & 11,033 & $16.9 \%$ & $18.8 \%$ & $\$ 12,622$ \\
\hline 12029 Dixie, FL & $36.0 \%$ & $8.3 \%$ & 10,657 & $10.0 \%$ & $27.4 \%$ & $\$ 12,707$ \\
\hline 12041 Gilchrist, FL & $29.0 \%$ & $6.6 \%$ & 9,745 & $10.1 \%$ & $17.5 \%$ & $\$ 12,888$ \\
\hline 12047 Hamilton, FL & $30.7 \%$ & $8.5 \%$ & 10,977 & $41.3 \%$ & $27.8 \%$ & $\$ 12,198$ \\
\hline 12059 Holmes, FL & $35.2 \%$ & $6.7 \%$ & 15,810 & $6.8 \%$ & $24.6 \%$ & $\$ 12,456$ \\
\hline 12067 Lafayette, FL & $23.0 \%$ & $4.5 \%$ & 5,617 & $17.6 \%$ & $23.8 \%$ & $\$ 12,375$ \\
\hline 12077 Liberty, FL & $34.7 \%$ & $3.5 \%$ & 5,584 & $19.3 \%$ & $16.6 \%$ & $\$ 12,856$ \\
\hline 12125 Union, FL & $22.7 \%$ & $4.9 \%$ & 10,280 & $25.1 \%$ & $15.8 \%$ & $\$ 9,944$ \\
\hline 12133 Washington, FL & $36.6 \%$ & $5.8 \%$ & 16,966 & $17.3 \%$ & $21.9 \%$ & $\$ 13,618$ \\
\hline 13000 GEORGIA & $14.9 \%$ & $5.6 \%$ & $6,506,247$ & $29.3 \%$ & $14.7 \%$ & $\$ 21,726$ \\
\hline 13039 Camden, GA & $13.3 \%$ & $4.4 \%$ & 30,801 & $24.4 \%$ & $11.5 \%$ & $\$ 13,636$ \\
\hline 13049 Charlton, GA & $26.5 \%$ & $7.6 \%$ & 8,493 & $28.2 \%$ & $18.3 \%$ & $\$ 13,176$ \\
\hline 13061 Clay, GA & $33.6 \%$ & $10.1 \%$ & 3,347 & $60.9 \%$ & $35.7 \%$ & $\$ 13,275$ \\
\hline 13149 Heard, GA & $23.5 \%$ & $5.3 \%$ & 8,682 & $14.6 \%$ & $19.1 \%$ & $\$ 13,886$ \\
\hline 13179 Liberty, GA & $17.9 \%$ & $6.0 \%$ & 52,838 & $45.2 \%$ & $17.2 \%$ & $\$ 12,113$ \\
\hline 13183 Long, GA & $20.3 \%$ & $8.7 \%$ & 6,321 & $25.9 \%$ & $23.7 \%$ & $\$ 11,002$ \\
\hline 13191 McIntosh, GA & $29.9 \%$ & $6.5 \%$ & 8,615 & $43.4 \%$ & $22.3 \%$ & $\$ 13,406$ \\
\hline 13197 Marion, GA & $24.5 \%$ & $10.3 \%$ & 5,578 & $41.7 \%$ & $28.2 \%$ & $\$ 13,122$ \\
\hline 13263 Talbot, GA & $26.1 \%$ & $9.3 \%$ & 6,539 & $62.7 \%$ & $24.9 \%$ & $\$ 13,530$ \\
\hline 21000 KENTUCKY & $19.8 \%$ & $7.2 \%$ & $3,692,528$ & $8.1 \%$ & $19.0 \%$ & $\$ 18,863$ \\
\hline 21011 Bath, KY & $28.5 \%$ & $9.6 \%$ & 9,712 & $3.3 \%$ & $27.3 \%$ & $\$ 13,025$ \\
\hline 21013 Bell, KY & $38.7 \%$ & $14.0 \%$ & 31,467 & $2.9 \%$ & $36.2 \%$ & $\$ 13,746$ \\
\hline 21025 Breathitt, KY & $39.3 \%$ & $15.0 \%$ & 15,665 & $0.2 \%$ & $39.5 \%$ & $\$ 12,934$ \\
\hline 21031 Butler, KY & $30.2 \%$ & $6.3 \%$ & 11,233 & $0.7 \%$ & $23.8 \%$ & $\$ 13,239$ \\
\hline 21045 Casey, KY & $28.8 \%$ & $7.5 \%$ & 14,182 & $0.5 \%$ & $29.4 \%$ & $\$ 12,244$ \\
\hline 21051 Clay, KY & $39.5 \%$ & $14.2 \%$ & 21,680 & $1.6 \%$ & $40.2 \%$ & $\$ 12,015$ \\
\hline 21053 Clinton, KY & $39.2 \%$ & $9.6 \%$ & 9,158 & $0.4 \%$ & $38.1 \%$ & $\$ 12,005$ \\
\hline 21057 Cumberland, $\mathrm{KY}$ & $37.3 \%$ & $8.3 \%$ & 6,769 & $4.6 \%$ & $31.6 \%$ & $\$ 11,854$ \\
\hline 21061 Edmonson, $K Y$ & $28.9 \%$ & $10.8 \%$ & 10,347 & $1.8 \%$ & $27.0 \%$ & $\$ 12,042$ \\
\hline
\end{tabular}




\section{APPENDIX TABLE A (Continued)}

\begin{tabular}{|c|c|c|c|c|c|c|}
\hline & $\begin{array}{c}\text { ansfer Paymen } \\
\text { Share of } \\
\text { Personal } \\
\text { Income 1993 } \\
\end{array}$ & $\begin{array}{l}\text { Unemployment } \\
\text { Rate 1990 }\end{array}$ & $\begin{array}{c}\text { Total Resident } \\
\text { Population } 1990 \\
\end{array}$ & $\begin{array}{c}\text { Percent } \\
\text { Non-White } \\
\text { Population } 1990^{*}\end{array}$ & $\begin{array}{c}\text { Percent } \\
\text { Population } \\
\text { Below Poverty } \\
\text { Level 1989 } \\
\end{array}$ & $\begin{array}{c}\text { Per Capita } \\
\text { Income } 1995 \\
\end{array}$ \\
\hline 21063 Elliott, KY & $35.7 \%$ & $17.6 \%$ & 6,444 & $0.0 \%$ & $38.0 \%$ & $\$ 9,229$ \\
\hline 21065 Estill, KY & $32.9 \%$ & $13.7 \%$ & 14,680 & $0.6 \%$ & $29.0 \%$ & $\$ 12,724$ \\
\hline 21069 Fleming, KY & $23.8 \%$ & $6.5 \%$ & 12,284 & $1.8 \%$ & $25.4 \%$ & $\$ 13,666$ \\
\hline 21087 Green, KY & $27.4 \%$ & $4.7 \%$ & 10,367 & $3.7 \%$ & $21.6 \%$ & $\$ 13,460$ \\
\hline 21095 Harlan, KY & $37.6 \%$ & $14.1 \%$ & 36,532 & $3.5 \%$ & $33.1 \%$ & $\$ 12,560$ \\
\hline 21099 Hart, KY & $26.7 \%$ & $8.4 \%$ & 14,914 & $7.6 \%$ & $27.1 \%$ & $\$ 13,525$ \\
\hline 21109 Jackson, $\mathrm{KY}$ & $36.8 \%$ & $12.4 \%$ & 11,986 & $0.4 \%$ & $38.2 \%$ & $\$ 11,398$ \\
\hline $21119 \mathrm{Knott}, \mathrm{KY}$ & $36.1 \%$ & $15.5 \%$ & 17,929 & $0.9 \%$ & $40.4 \%$ & $\$ 12,073$ \\
\hline 21121 Knox, KY & $36.3 \%$ & $12.6 \%$ & 29,673 & $1.4 \%$ & $38.9 \%$ & $\$ 12,361$ \\
\hline 21127 Lawrence, KY & $34.2 \%$ & $16.9 \%$ & 14,010 & $0.6 \%$ & $36.0 \%$ & $\$ 12,285$ \\
\hline 21129 Lee, KY & $42.0 \%$ & $14.0 \%$ & 7,428 & $0.5 \%$ & $37.4 \%$ & $\$ 11,706$ \\
\hline 21131 Leslie, KY & $34.2 \%$ & $12.2 \%$ & 13,621 & $0.1 \%$ & $35.6 \%$ & $\$ 13,329$ \\
\hline 21133 Letcher, $\mathrm{KY}$ & $36.5 \%$ & $13.8 \%$ & 26,998 & $1.0 \%$ & $31.8 \%$ & $\$ 12,924$ \\
\hline 21135 Lewis, KY & $32.4 \%$ & $9.5 \%$ & 12,997 & $0.2 \%$ & $30.7 \%$ & $\$ 11,477$ \\
\hline 21143 Lyon, KY & $25.9 \%$ & $8.2 \%$ & 6,642 & $7.4 \%$ & $14.3 \%$ & $\$ 13,114$ \\
\hline 21147 McCreary, KY & $47.5 \%$ & $20.3 \%$ & 15,630 & $1.4 \%$ & $45.5 \%$ & $\$ 10,841$ \\
\hline 21153 Magoffin, KY & $40.6 \%$ & $18.4 \%$ & 13,113 & $0.5 \%$ & $42.5 \%$ & $\$ 11,283$ \\
\hline 21165 Menifee, KY & $33.1 \%$ & $12.6 \%$ & 5,115 & $2.5 \%$ & $35.0 \%$ & $\$ 11,349$ \\
\hline 21169 Metcalfe, KY & $27.0 \%$ & $5.7 \%$ & 8,961 & $2.8 \%$ & $27.9 \%$ & $\$ 13,752$ \\
\hline 21175 Morgan, KY & $33.2 \%$ & $12.6 \%$ & 11,690 & $1.3 \%$ & $38.8 \%$ & $\$ 9,996$ \\
\hline 21183 Ohio, KY & $29.2 \%$ & $11.5 \%$ & 21,088 & $1.1 \%$ & $23.6 \%$ & $\$ 13,621$ \\
\hline 21189 Owsley, KY & $54.5 \%$ & $17.2 \%$ & 5,032 & $0.3 \%$ & $52.1 \%$ & $\$ 10,637$ \\
\hline 21197 Powell, KY & $29.8 \%$ & $15.0 \%$ & 11,651 & $0.7 \%$ & $26.2 \%$ & $\$ 12,336$ \\
\hline 21201 Robertson, KY & $26.9 \%$ & $7.9 \%$ & 2,114 & $0.0 \%$ & $24.8 \%$ & $\$ 13,449$ \\
\hline 21203 Rockcastle, $\mathrm{KY}$ & $31.1 \%$ & $12.1 \%$ & 14,822 & $0.4 \%$ & $30.7 \%$ & $\$ 12,712$ \\
\hline 21205 Rowan, KY & $25.3 \%$ & $10.7 \%$ & 20,421 & $2.7 \%$ & $28.9 \%$ & $\$ 12,653$ \\
\hline 21231 Wayne, KY & $34.4 \%$ & $9.2 \%$ & 17,486 & $2.2 \%$ & $37.3 \%$ & $\$ 12,167$ \\
\hline 21235 Whitley, KY & $36.2 \%$ & $14.2 \%$ & 33,334 & $1.0 \%$ & $33.0 \%$ & $\$ 13,914$ \\
\hline 21237 Wolfe, KY & $44.8 \%$ & $15.6 \%$ & 6,464 & $0.0 \%$ & $44.3 \%$ & $\$ 11,391$ \\
\hline 22000 LOUISIANA & $21.7 \%$ & $9.5 \%$ & $4,217,357$ & $32.7 \%$ & $23.6 \%$ & $\$ 18,997$ \\
\hline 22003 Allen, LA & $34.3 \%$ & $11.5 \%$ & 21,207 & $23.1 \%$ & $29.9 \%$ & $\$ 13,246$ \\
\hline 22035 East Carroll, LA & $40.4 \%$ & $24.0 \%$ & 9,645 & $65.2 \%$ & $56.8 \%$ & $\$ 12,848$ \\
\hline 22065 Madison, LA & $38.5 \%$ & $15.6 \%$ & 12,411 & $60.0 \%$ & $44.6 \%$ & $\$ 13,773$ \\
\hline 22091 St. Helena, LA & $28.0 \%$ & $13.7 \%$ & 9,859 & $52.1 \%$ & $34.4 \%$ & $\$ 13,465$ \\
\hline 22123 West Carroll, LA & $33.5 \%$ & $11.9 \%$ & 12,087 & $17.3 \%$ & $27.4 \%$ & $\$ 12,966$ \\
\hline 22125 West Feliciana, LA & $20.5 \%$ & $6.8 \%$ & 12,915 & $43.9 \%$ & $33.8 \%$ & $\$ 12,035$ \\
\hline 28000 MISSISSIPPI & $22.5 \%$ & $8.3 \%$ & $2,577,258$ & $36.6 \%$ & $25.2 \%$ & $\$ 16,716$ \\
\hline 28005 Amite, MS & $30.7 \%$ & $9.0 \%$ & 13,264 & $45.2 \%$ & $30.9 \%$ & $\$ 11,421$ \\
\hline 28009 Benton, MS & $30.7 \%$ & $15.1 \%$ & 8,027 & $39.3 \%$ & $29.7 \%$ & $\$ 12,769$ \\
\hline 28015 Carroll, MS & $25.0 \%$ & $10.1 \%$ & 9,237 & $39.8 \%$ & $28.5 \%$ & $\$ 13,156$ \\
\hline 28019 Choctaw, MS & $28.9 \%$ & $9.7 \%$ & 9,083 & $30.4 \%$ & $25.0 \%$ & $\$ 12,644$ \\
\hline 28021 Claiborne, MS & $29.9 \%$ & $20.3 \%$ & 11,371 & $82.5 \%$ & $43.6 \%$ & $\$ 11,843$ \\
\hline 28029 Copiah, MS & $29.7 \%$ & $9.4 \%$ & 27,641 & $50.8 \%$ & $32.0 \%$ & $\$ 13,484$ \\
\hline 28037 Franklin, MS & $33.3 \%$ & $13.3 \%$ & 8,344 & $36.6 \%$ & $33.3 \%$ & $\$ 12,162$ \\
\hline 28039 George, MS & $25.7 \%$ & $10.4 \%$ & 16,721 & $10.1 \%$ & $24.4 \%$ & $\$ 13,654$ \\
\hline 28041 Greene, MS & $30.0 \%$ & $10.9 \%$ & 10,252 & $22.0 \%$ & $26.8 \%$ & $\$ 11,479$ \\
\hline 28051 Holmes, MS & $42.4 \%$ & $15.8 \%$ & 21,563 & $76.0 \%$ & $53.2 \%$ & $\$ 12,152$ \\
\hline 28055 Issaquena, MS & $20.2 \%$ & $10.0 \%$ & 1,908 & $56.3 \%$ & $49.3 \%$ & $\$ 10,668$ \\
\hline 28061 Jasper, MS & $28.8 \%$ & $10.4 \%$ & 17,096 & $50.8 \%$ & $30.7 \%$ & $\$ 13,895$ \\
\hline 28063 Jefferson, MS & $49.8 \%$ & $25.5 \%$ & 8,600 & $86.2 \%$ & $46.9 \%$ & $\$ 10,479$ \\
\hline 28065 Jefferson Davis, MS & $32.3 \%$ & $11.7 \%$ & 14,005 & $54.8 \%$ & $33.3 \%$ & $\$ 12,425$ \\
\hline 28069 Kemper, MS & $29.4 \%$ & $11.2 \%$ & 10,327 & $57.3 \%$ & $35.1 \%$ & $\$ 13,405$ \\
\hline 28077 Lawrence, MS & $33.0 \%$ & $7.6 \%$ & 12,460 & $33.4 \%$ & $27.9 \%$ & $\$ 13,806$ \\
\hline 28091 Marion, MS & $32.6 \%$ & $10.8 \%$ & 25,512 & $30.5 \%$ & $29.6 \%$ & $\$ 13,274$ \\
\hline 28103 Noxubee, MS & $32.0 \%$ & $15.5 \%$ & 12,608 & $68.6 \%$ & $41.4 \%$ & $\$ 12,539$ \\
\hline
\end{tabular}


APPENDIX TABLE A (Continued)

\begin{tabular}{|c|c|c|c|c|c|c|}
\hline & $\begin{array}{l}\text { ansfer Paymen } \\
\text { Share of } \\
\text { Personal } \\
\text { Income } 1993\end{array}$ & $\begin{array}{l}\text { ts } \\
\text { Unemployment } \\
\text { Rate } 1990\end{array}$ & $\begin{array}{c}\text { Total Resident } \\
\text { Population } 1990\end{array}$ & $\begin{array}{c}\text { Percent } \\
\text { Non-White } \\
\text { Population 1990* }\end{array}$ & $\begin{array}{c}\text { Percent } \\
\text { Population } \\
\text { Below Poverty } \\
\text { Level 1989 }\end{array}$ & $\begin{array}{c}\text { Per Capita } \\
\text { Income } 1995\end{array}$ \\
\hline 28109 Pearl River, MS & $27.4 \%$ & $8.6 \%$ & 38,821 & $15.3 \%$ & $21.5 \%$ & $\$ 13,705$ \\
\hline 28111 Perry, MS & $30.7 \%$ & $9.2 \%$ & 10,848 & $23.2 \%$ & $29.1 \%$ & $\$ 11,987$ \\
\hline 28119 Quitman, MS & $37.4 \%$ & $11.8 \%$ & 10,426 & $59.2 \%$ & $41.6 \%$ & $\$ 12,290$ \\
\hline 28125 Sharkey, MS & $35.5 \%$ & $10.1 \%$ & 7,030 & $66.7 \%$ & $47.5 \%$ & $\$ 12,116$ \\
\hline 28133 Sunflower, MS & $27.0 \%$ & $10.8 \%$ & 35,035 & $66.9 \%$ & $41.8 \%$ & $\$ 11,693$ \\
\hline 28135 Tallahatchie, MS & $35.7 \%$ & $13.3 \%$ & 15,191 & $58.8 \%$ & $41.9 \%$ & $\$ 11,460$ \\
\hline 28147 Walthall, MS & $33.9 \%$ & $9.9 \%$ & 14,382 & $42.6 \%$ & $35.9 \%$ & $\$ 12,511$ \\
\hline 28157 Wilkinson, MS & $36.6 \%$ & $16.8 \%$ & 9,698 & $67.8 \%$ & $42.2 \%$ & $\$ 11,965$ \\
\hline 37000 NORTH CAROLINA & A $16.2 \%$ & $4.6 \%$ & $6,656,659$ & $24.8 \%$ & $13.0 \%$ & $\$ 21,079$ \\
\hline 37093 Hoke, NC & $23.5 \%$ & $7.1 \%$ & 22,925 & $58.0 \%$ & $21.1 \%$ & $\$ 12,334$ \\
\hline 37173 Swain, NC & $32.3 \%$ & $10.7 \%$ & 11,296 & $29.6 \%$ & $27.6 \%$ & $\$ 13,399$ \\
\hline 37177 Tyrrell, NC & $28.7 \%$ & $10.9 \%$ & 3,856 & $40.4 \%$ & $25.0 \%$ & $\$ 13,712$ \\
\hline 40000 OKLAHOMA & $20.0 \%$ & $6.7 \%$ & $3,147,046$ & $17.9 \%$ & $16.7 \%$ & $\$ 18,601$ \\
\hline 40005 Atoka, OK & $32.8 \%$ & $11.0 \%$ & 12,757 & $18.8 \%$ & $31.1 \%$ & $\$ 11,372$ \\
\hline 40023 Choctaw, OK & $33.3 \%$ & $10.7 \%$ & 15,312 & $28.6 \%$ & $32.7 \%$ & $\$ 13,316$ \\
\hline 40029 Coal, OK & $38.7 \%$ & $11.2 \%$ & 5,742 & $17.2 \%$ & $27.4 \%$ & $\$ 11,081$ \\
\hline 40061 Haskell, OK & $34.0 \%$ & $10.4 \%$ & 10,948 & $15.8 \%$ & $27.1 \%$ & $\$ 13,296$ \\
\hline 40063 Hughes, OK & $37.9 \%$ & $11.2 \%$ & 12,973 & $20.2 \%$ & $26.9 \%$ & $\$ 12,996$ \\
\hline 40069 Johnston, OK & $34.1 \%$ & $10.5 \%$ & 10,023 & $18.5 \%$ & $28.5 \%$ & $\$ 12,069$ \\
\hline 40091 McIntosh, OK & $36.1 \%$ & $10.0 \%$ & 16,775 & $24.0 \%$ & $23.8 \%$ & $\$ 13,565$ \\
\hline 40105 Nowata, OK & $27.5 \%$ & $6.8 \%$ & 9,941 & $19.8 \%$ & $20.9 \%$ & $\$ 13,894$ \\
\hline 40107 Okfuskee, OK & $35.7 \%$ & $10.1 \%$ & 11,568 & $32.3 \%$ & $29.4 \%$ & $\$ 12,639$ \\
\hline 40127 Pushmataha, OK & $38.8 \%$ & $11.8 \%$ & 10,974 & $16.5 \%$ & $30.2 \%$ & $\$ 12,531$ \\
\hline 40141 Tillman, OK & $28.9 \%$ & $10.9 \%$ & 10,322 & $23.9 \%$ & $22.9 \%$ & $\$ 13,208$ \\
\hline 45000 SOUTH CAROLINA & A $18.4 \%$ & $5.4 \%$ & $3,498,928$ & $31.2 \%$ & $15.4 \%$ & $\$ 19,037$ \\
\hline 45005 Allendale, SC & $32.2 \%$ & $11.0 \%$ & 11,741 & $69.0 \%$ & $35.8 \%$ & $\$ 13,708$ \\
\hline 45027 Clarendon, SC & $30.6 \%$ & $8.1 \%$ & 28,463 & $56.9 \%$ & $29.0 \%$ & $\$ 13,678$ \\
\hline 45061 Lee, SC & $28.2 \%$ & $9.0 \%$ & 18,441 & $62.9 \%$ & $29.6 \%$ & $\$ 12,397$ \\
\hline 4565 McCormick, SC & $25.9 \%$ & $8.5 \%$ & 8,868 & $58.9 \%$ & $22.8 \%$ & $\$ 13,018$ \\
\hline 45069 Marlboro, SC & $28.8 \%$ & $9.5 \%$ & 29,748 & $51.9 \%$ & $26.6 \%$ & $\$ 13,171$ \\
\hline 45089 Williamsburg, SC & $28.1 \%$ & $7.4 \%$ & 36,757 & $64.4 \%$ & $28.7 \%$ & $\$ 13,111$ \\
\hline 47000 TENNESSEE & $17.8 \%$ & $6.3 \%$ & $4,890,644$ & $17.2 \%$ & $15.7 \%$ & $\$ 21,060$ \\
\hline 47007 Bledsoe, TN & $24.7 \%$ & $7.7 \%$ & 9,683 & $4.6 \%$ & $19.2 \%$ & $\$ 13,424$ \\
\hline 47067 Hancock, TN & $40.1 \%$ & $10.6 \%$ & 6,742 & $2.2 \%$ & $40.0 \%$ & $\$ 11,479$ \\
\hline 47083 Houston, TN & $30.7 \%$ & $8.7 \%$ & 7,002 & $4.0 \%$ & $18.7 \%$ & $\$ 13,403$ \\
\hline 47091 Johnson, TN & $35.5 \%$ & $8.3 \%$ & 13,804 & $1.0 \%$ & $28.5 \%$ & $\$ 11,948$ \\
\hline 47095 Lakè, TN & $33.0 \%$ & $9.1 \%$ & 7,113 & $23.8 \%$ & $27.5 \%$ & $\$ 11,342$ \\
\hline 47121 Meigs, TN & $25.7 \%$ & $6.9 \%$ & 8,092 & $2.6 \%$ & $22.3 \%$ & $\$ 13,652$ \\
\hline 47129 Morgan, TN & $31.6 \%$ & $11.3 \%$ & 17,335 & $2.2 \%$ & $20.2 \%$ & $\$ 12,373$ \\
\hline $47151 \mathrm{Scott}, \mathrm{TN}$ & $36.1 \%$ & $10.1 \%$ & 18,375 & $0.6 \%$ & $27.8 \%$ & $\$ 13,896$ \\
\hline 47175 Van Buren, TN & $21.9 \%$ & $11.5 \%$ & 4,851 & $0.6 \%$ & $19.2 \%$ & $\$ 12,277$ \\
\hline 47181 Wayne, TN & $22.2 \%$ & $4.6 \%$ & 13,966 & $1.5 \%$ & $18.7 \%$ & $\$ 13,128$ \\
\hline 48000 TEXAS & $15.0 \%$ & $7.0 \%$ & $17,045,646$ & $25.1 \%$ & $18.1 \%$ & $\$ 21,118$ \\
\hline 48025 Bee, TX & $27.3 \%$ & $10.0 \%$ & 24,962 & $22.1 \%$ & $27.4 \%$ & $\$ 13,681$ \\
\hline 48047 Brooks, TX & $34.9 \%$ & $12.1 \%$ & 8,182 & $17.5 \%$ & $36.8 \%$ & $\$ 11,673$ \\
\hline 48095 Concho, TX & $30.3 \%$ & $4.0 \%$ & 3,059 & $11: 1 \%$ & $25.8 \%$ & $\$ 13,512$ \\
\hline 48109 Culberson, TX & $22.4 \%$ & $11.2 \%$ & 3,407 & $29.6 \%$ & $29.8 \%$ & $\$ 10,508$ \\
\hline 48127 Dimmit, TX & $36.6 \%$ & $13.7 \%$ & 10,390 & $26.9 \%$ & $48.9 \%$ & $\$ 9,948$ \\
\hline 48131 Duval, TX & $36.7 \%$ & $14.9 \%$ & 12,862 & $20.8 \%$ & $39.0 \%$ & $\$ 10,989$ \\
\hline 48137 Edwards, TX & $21.8 \%$ & $4.6 \%$ & 2,285 & $7.5 \%$ & $41.7 \%$ & $\$ 11,196$ \\
\hline 48141 El Paso, TX & $21.8 \%$ & $10.0 \%$ & 596,267 & $24.1 \%$ & $26.8 \%$ & $\$ 13,702$ \\
\hline 48163 Frio, $T X$ & $28.5 \%$ & $8.1 \%$ & 13,545 & $32.7 \%$ & $39.1 \%$ & $\$ 10,962$ \\
\hline
\end{tabular}


APPENDIX TABLE A (Continued)

\begin{tabular}{|c|c|c|c|c|c|c|}
\hline & $\begin{array}{l}\text { Transfer Payment } \\
\text { Share of } \\
\text { Personal } \\
\text { Income 1993 }\end{array}$ & $\begin{array}{l}\text { Unemployment } \\
\text { Rate } 1990\end{array}$ & $\begin{array}{c}\text { Total Resident } \\
\text { Population } 1990\end{array}$ & $\begin{array}{c}\text { Percent } \\
\text { Non-White } \\
\text { Population 1990* }\end{array}$ & $\begin{array}{c}\text { Percent } \\
\text { Population } \\
\text { Below Poverty } \\
\text { Level 1989 } \\
\end{array}$ & $\begin{array}{l}\text { Per Capita } \\
\text { Income } 1995\end{array}$ \\
\hline 48173 Glasscock, TX & $8.4 \%$ & $2.2 \%$ & 1,443 & $19.9 \%$ & $22.3 \%$ & $\$ 13,110$ \\
\hline 48229 Hudspeth, TX & $22.2 \%$ & $3.5 \%$ & 2,912 & $19.5 \%$ & $38.9 \%$ & $\$ 10,010$ \\
\hline 48269 King, TX & $10.4 \%$ & $2.0 \%$ & 354 & $10.5 \%$ & $7.3 \%$ & $\$ 13,604$ \\
\hline 48271 Kinney, TX & $33.9 \%$ & $6.8 \%$ & 3,132 & $12.3 \%$ & $28.6 \%$ & $\$ 10,554$ \\
\hline 48283 La Salle, TX & $28.4 \%$ & $11.0 \%$ & 5,277 & $32.4 \%$ & $37.0 \%$ & $\$ 10,248$ \\
\hline 48323 Maverick, TX & $35.7 \%$ & $21.0 \%$ & 36,800 & $35.5 \%$ & $50.4 \%$ & $\$ 8,428$ \\
\hline 48335 Mitchell, TX & $29.2 \%$ & $6.7 \%$ & 7,945 & $20.5 \%$ & $23.3 \%$ & $\$ 13,709$ \\
\hline 48351 Newton, TX & $28.5 \%$ & $12.0 \%$ & 13,524 & $23.1 \%$ & $26.5 \%$ & $\$ 13,529$ \\
\hline 48371 Pecos, TX & $22.2 \%$ & $8.7 \%$ & 14,615 & $35.3 \%$ & $29.6 \%$ & $\$ 11,436$ \\
\hline 48377 Presidio, TX & $31.7 \%$ & $10.3 \%$ & 6,734 & $16.5 \%$ & $48.1 \%$ & $\$ 9,539$ \\
\hline 48379 Rains, TX & $24.6 \%$ & $5.9 \%$ & 6,725 & $6.2 \%$ & $15.0 \%$ & $\$ 13,599$ \\
\hline 48389 Reeves, TX & $22.4 \%$ & $11.7 \%$ & 15,767 & $3.0 \%$ & $28.8 \%$ & $\$ 11,409$ \\
\hline 48427 Starr, TX & $39.2 \%$ & $18.8 \%$ & 40,870 & $38.7 \%$ & $60.0 \%$ & $\$ 6,992$ \\
\hline 48431 Sterling, TX & $18.5 \%$ & $2.3 \%$ & 1,429 & $12.9 \%$ & $14.3 \%$ & $\$ 13,244$ \\
\hline 48465 Val Verde, TX & $26.3 \%$ & $12.3 \%$ & 38,636 & $30.9 \%$ & $36.4 \%$ & $\$ 12,077$ \\
\hline 48471 Walker, TX & $20.5 \%$ & $7.0 \%$ & 50,882 & $31.3 \%$ & $22.3 \%$ & $\$ 13,574$ \\
\hline 48489 Willacy, TX & $33.3 \%$ & $15.0 \%$ & 17,696 & $21.9 \%$ & $44.5 \%$ & $\$ 10,029$ \\
\hline 48505 Zapata, TX & $33.4 \%$ & $14.4 \%$ & 9,330 & $28.4 \%$ & $41.0 \%$ & $\$ 10,840$ \\
\hline 48507 Zavala, TX & $36.3 \%$ & $19.7 \%$ & 12,176 & $47.1 \%$ & $50.4 \%$ & $\$ 8,293$ \\
\hline 51000 VIRGINIA & $14.4 \%$ & $4.3 \%$ & $6,213,836$ & $22.9 \%$ & $10.2 \%$ & $\$ 24,010$ \\
\hline 51021 Bland, VA & $21.7 \%$ & $3.6 \%$ & 6,530 & $4.2 \%$ & $10.0 \%$ & $\$ 13,682$ \\
\hline 51105 Lee, VA & $35.0 \%$ & $10.3 \%$ & 24,442 & $0.4 \%$ & $28.7 \%$ & $\$ 13,556$ \\
\hline 54000 WEST VIRGINIA & $27.0 \%$ & $9.6 \%$ & $1,792,450$ & $3.7 \%$ & $19.7 \%$ & $\$ 17,733$ \\
\hline 54001 Barbour, WV & $35.9 \%$ & $13.1 \%$ & 15,686 & $2.3 \%$ & $28.5 \%$ & $\$ 12,542$ \\
\hline 54013 Calhoun, WV & $38.5 \%$ & $13.9 \%$ & 7,890 & $0.7 \%$ & $32.0 \%$ & $\$ 11,854$ \\
\hline 54015 Clay, WV & $38.4 \%$ & $19.8 \%$ & 9,953 & $0.0 \%$ & $39.2 \%$ & $\$ 11,737$ \\
\hline 54017 Doddridge, WV & $26.1 \%$ & $11.5 \%$ & 7,005 & $0.8 \%$ & $23.0 \%$ & $\$ 12,546$ \\
\hline 54027 Hampshire, WV & $25.5 \%$ & $7.8 \%$ & 16,596 & $1.7 \%$ & $18.2 \%$ & $\$ 13,791$ \\
\hline 54043 Lincoln, WV & $34.8 \%$ & $16.4 \%$ & 21,372 & $0.2 \%$ & $33.8 \%$ & $\$ 11,893$ \\
\hline 54047 McDowell, WV & $48.3 \%$ & $21.9 \%$ & 34,991 & $13.1 \%$ & $37.7 \%$ & $\$ 12,590$ \\
\hline 54063 Monroe, WV & $32.3 \%$ & $10.8 \%$ & 12,398 & $1.5 \%$ & $21.0 \%$ & $\$ 13,540$ \\
\hline 54085 Ritchie, WV & $31.8 \%$ & $11.9 \%$ & 10,246 & $0.3 \%$ & $26.0 \%$ & $\$ 13,466$ \\
\hline 54087 Roane, WV & $32.7 \%$ & $16.1 \%$ & 15,019 & $0.0 \%$ & $28.1 \%$ & $\$ 13,030$ \\
\hline 54089 Summers, WV & $43.8 \%$ & $13.6 \%$ & 14,110 & $5.4 \%$ & $24.5 \%$ & $\$ 12,555$ \\
\hline 54091 Taylor, WV & $33.8 \%$ & $12.6 \%$ & 15,115 & $0.8 \%$ & $22.9 \%$ & $\$ 13,040$ \\
\hline 54097 Upshur, WV & $27.9 \%$ & $9.6 \%$ & 22,890 & $1.1 \%$ & $21.2 \%$ & $\$ 13,661$ \\
\hline 54101 Webster, WV & $42.5 \%$ & $20.3 \%$ & 10,692 & $0.0 \%$ & $34.8 \%$ & $\$ 11,583$ \\
\hline 54105 Wirt, WV & $30.0 \%$ & $13.3 \%$ & 5,171 & $0.0 \%$ & $22.0 \%$ & $\$ 12,535$ \\
\hline 54109 Wyoming, WV & $37.2 \%$ & $16.4 \%$ & 28,957 & $1.0 \%$ & $27.9 \%$ & $\$ 13,087$ \\
\hline
\end{tabular}

"Non-white population includes Black; American Indian, Eskimo, Aleutian; Asian \& Pacific Islander; and Other 


\section{REFERENCES}

Aiken, C.S. "The Rural South: A Historical View." The Changing American Countryside. Lawrence, KA: The University of Kansas Press, 1995.

Bailey, A.S. and W.J. Coffey. "Regional Science in Crisis: A Plea for a More Open and Relevant Approach." Papers in Regional Science 73 (1994): 3-14.

Barkley, David L. "The Economics of Change in Rural America." American Journal of Agricultural Economics 77 (December 1995): 1252-1258.

ed. Economic Adaption: Alternatives for Nonmetropolitan Areas. Boulder,

CO: Westview Press, 1993.

Batten, D.F. "Culture and Region Revisited." Papers in Regional Science 72 (1993): 103-112.

Billings, Dwight B. "The Rural South in Crisis: A Historical Perspective." The Rural South in Crisis: Challenges for the Future. Boulder, CO: Westview Press, 1988.

Blakely, Edward J. Planning Local Economic Development: Theory and Practice. 2d ed. Thousand Oaks, CA: Sage, 1994.

Bolton, R. "Some Notes on Social Capital." Paper presented at the North American Meetings of the Regional Science Association International, Buffalo, NY, November 1997.

- "Place as 'Network': Applications of Network Theory to Local Communities." Paper presented at the North American Regional Science Meetings, Arlington, VA, 1996.

. "New Regional Science and New Economics." Australian Journal of Regional Science 191 (1995): 31-38.

- "Place Prosperity vs. People Prosperity Revisited: An Old Issue with a New Angle." Urban Studies 29 (1992): 185-203.

Coffey, W.J. and M. Polése. "The Concept of Local Development: A Stages Model of Endogenous Regional Growth." Papers of the Regional Science Association 55 (1984): 1-12.

Coffey, W.J. "Comprehensive Bases for Locally Induced Development." Alternative Perspectives on Development Prospects for Rural Areas. Vancouver, B.C.: AAEA, 1990.

Cook, P.J. and K.L. Mizer. "The Revised ERS County Typology: An Overview." Rural Development Report 89 (1989).

Doeringer, P.B. and D.G. Terkla. "How Intangible Factors Contribute to Economic Development: Lessons from a Mature Economy." World Development 18 (1990): 1295-1308.

Flora, J.L., G.P. Green, E.A. Gale, F.E. Schmidt, and C.B. Flora. “Self-Development: A Viable Rural Development Option." Policy Studies Journal 20 (1992): 276-288. Galston, W.A. and K.J. Baehler. Rural Development in the United States: Connecting Theory, Practice, and Possibilities. Washington, D.C.: Island Press, 1995. 
Gaventa, John. "The South Today: Poverty and Social Capital." The Changing American Countryside: Past, Present, and Future. Corvallis, OR: Western Rural Development Center, 1995: 53-62.

Green, G.P., J.L. Flora, and F.E. Schmidt. "Community-Based Economic Development Projects are Small but Valuable." Rural Development Perspectives 8 (1993): 8-15.

Hansen, Niles. "Endogeneous Regional Development: Lessons from the LanguedocRoussillon and Montpellier." Paper presented at the annual meetings of the Western Regional Science Association, Monterey, CA, February 1998.

"Addressing Regional Disparity and Equity Objectives Through Regional Policies: A Skeptical Perspective." Papers in Regional Science 74 (1995): 89-104.

Henry, M.S., D.L. Barkley, and S. Bao. "The Hinterlands' Stake in Metropolitan Growth: Evidence from Selected Southern Regions." Journal of Regional Science 37 (1997): 479- 501.

Henry, M., M. Drabenstott, and L. Gibson. "A Changing Rural Economy." Rural American in Transition. Kansas City, MO: The Federal Reserve Bank of Kansas City, 1988: 15-39.

Hobbs, D. "Social Organization in the Countryside." The Changing American Countryside. Lawrence, KS: University of Kansas Press, 1995: 369-396.

Kale, S.R. "Theoretical Contributions to the Understanding of U.S. Nonmetropolitan Economic Change." Economic Development Quarterly 3 (1989): 58-69. Leatherman, J.C. and D.W. Marcouiller. "Income Distribution Characteristics of Rural Economic Sectors: Implications for Local Economic Development Policy." Growth and Change 27 (1996): 434-459.

Malecki, E.J. "How Development Occurs: Local Knowledge, Social Capital, and Institutional Embededness." Paper presented at the Southern Regional Science Association annual meetings, Savannah, GA, April 1998.

Marsh, B. "Continuity and Decline in the Anthracite Towns of Pennsylvania." Annuals of the Association of American Geographers 77 (1987): 337-352.

McDowell, G.R. "Some Communities are Successful, Others Are Not: Toward An Institutional Framework for Understanding the Reasons Why." Rural Development Strategies. Chicago, IL: Nelson-Hall, 1995: 269-281.

MDC, Inc. Coming Out of the Shadows: The Changing Face of Rural Development in the South. Chapel Hill, NC, 1992.

Mulkey, D., E.J. Malecki, and J. Burkhardt. "A Functional Community Perspective on Rural Development Policy." Staff Paper SP 93-7, Development of Food and Resource Economics, University of Florida, Gainesville, 1993.

Nelson, R. "Recent Evolutionary Theorizing About Economic Change." The Journal of Economic Literature 33 (1995): 48-90.

North, D.C. "Economic Performance Through Time." American Economic Review (1994): 359- 367. 
Olson, M. The Rise and Decline of Nations. New Haven, CT: Yale University Press, 1982. Pred, A. Place, Practice, and Structure. Tostowa, NJ: Barnes and Noble Books, 1986. Putnam, R. "The Prosperous Community: Social Capital and Public Life." The American Prospect (Spring 1993): 35-42.

Ramsay, M. Community, Culture, and Economic Development. Albany, NY: State University of New York Press, 1995.

Smith, S.M. "The Theoretical Foundation of Rural Economic Development Policy." Paper presented at the Southern Regional Science Association Meetings, Baltimore, MD, April 1996.

Tomaskovic-Devey, D. Sundown on the Sunbelt? Growth Without Development in the Rural South. Raleigh, NC: Department of Sociology, North Carolina State University, 1991.

Wilson, P. "Empowerment: Community Economic Development from the Inside Out." Urban Studies 33 (1996): 617-630.

Wright, G. "The Economic Revolution in the American South." Economic Perspectives 1 (1987): 161-178. 
